\title{
The Research of Options for the Innovation Heat Treatment of the Tools for Coinage in Or- der to Increase their Lifetime
}

\author{
Miroslava Ťavodová ${ }^{1}$, Daniela Kalincová ${ }^{1}$, Rudolf Kaštan ${ }^{2}$ \\ ${ }^{1}$ Faculty of Environmental and Manufacturing Technology, Technical University in Zvolen, Študentská 26, 960 53. Slo- \\ vak republic.E-mail: tavodova@tuzvo.sk, kalincova@tuzvo.sk. \\ ${ }^{2}$ Mincovňa Kremnica, State Enterprise. Slovak Republic. E-mail: rudolf.kastan@ gmail.com
}

This paper describes research in technology of the heat treatment for tool steel Böhler K455 designed for cold work. The aim of the research was based on operational experiments to draft procedures for heat treatment of the tools in a vacuum hardening furnace. Testing of two alternative methods and comparison of the state of microstructure and the mechanical properties with the current state of these indicators of dies quality will highlight the importance of introducing innovations to achieve higher lifetime of dies and the justification for the purchase of new technological equipment.

Keywords: coining dies, heat treatment, innovation, quality of properties, lifetime

\section{References}

[1] ŠUGÁR, P., ŠUGÁROVÁ, J. (2009). Výrobné technológie: zlievanie, zváranie, tvárnenie. Banská Bystrica DALIBB, 2009, 291 s. ISBN 978-80-89090-587.

[2] ZDRAVECKÁ, E., FECSU, Š. (2010). Zvyšovanie životnosti nástrojov pri tvárnení za studena. [online]. 2012. [cit. 2012-11-16] Dostupné na internete: < http://www.tribotechnika.sk/tribotechnika-22010/zvysovanie-zivotnosti-nastrojov-pri-tvarneni-za-studena.html $>$.

[3] FREMUNT, P., KREJČÍK, J., PODRÁBSKÝ, T., (1994). Nástrojové oceli, Dum techniky Brno 1994, 229 s.,

[4] BÖHLER. 2013. K 455 - prospekt firmy. [online]. 2013. [cit. 2013.05.16] Dostupné na internete: http://www.bohler.sk/slovak/files/downloads/023_BOHLER_K455.pdf

[5] VOJTĚCH, D., (2010). Materiály a jejich mezní stavy, Vysoká škola chemicko-technologická v Prahe, 212 s., ISBN 978-800-7080-741-5

[6] VALÁŠEK, P. (2015). Influence of Surface Treatment of Steel Adherends on Shear Strength of Filled Resins. Manufacturing Technology, Vol. 15, No. 3, ISSN 1213-248

[7] HRUBÝ, J., RENTKA, J., SCHINDLEROVÁ, V., KREJČÍ, L., ŠEVČÍKOVÁ, X. (2013). Possibilities of prediction of service life of forming tools. Manufacturing Technology, Vol. 13, No. 2, pp. 178-181, ISSN 1213-2489.

[8] HRUBÝ, J., SCHINDLEROVÁ, V., RENTKA, J. (2015). Degradation Processes in the Contact Layers of Forming Tools. Manufacturing Technology, Vol. 15, No.5, pp. 836-842, ISSN 1213-2489 26. 